\title{
Long live science!
}

\section{Maxim Gorky (1868-1936), Russian author and friend of Lenin, gave this historic speech on behalf of science at the first public meeting of the "Free Association for the Development and Propagation of the Positive Sciences" in April 1917, under Kerensky's provisional government.}

$\mathrm{M}$ OST honoured citizens! It will probably seem strange to you that I have decided to bother you with a layman's opinions on science and its significance in the life of reborn Russia, and on the role to be played by science and technology in the new Russian history.

But maybe I shall be able to shake your natural and understandable sceptical attitude to my impudence, if you will permit me to set out briefly my attitude to experimental science and my opinion on the creative work which science can and must accomplish in our spiritually warped country.

Esteemed citizens! I do not know of any forces more creative and more apt for educating social instincts than the forces of art and science. I will say more-being in a known and modest degree a representative of art, I would quite sincerely and consciously put science in first place in the process of man's education.

For art is emotional; all too easily it succumbs to the subjective peculiarities of the creator's psyche; it is too dependent on what is conventionally called mood, and, for these reasons, it is rarely truly free, it rarely transcends the barriers imposed by the powerful influences of individualism, class, and national and racial prejudices.

The experimental sciences, which have developed mightily in the grateful soil of exact observation, are guided by the iron logic of mathematics, completely free from these influences. The spirit of the experimental sciences is truly international and for all humanity. We have the right to speak of Russian, German, or Italian art, but there exists only a single, universal, planetary science, and this gives wings to our thought, raising it up to the limits of universal mysteries, as clues to the tragedy of our existence; this opens u! to the world the path to unity, freedom and beauty.

It is not for me to convince you that it is necessary to fill our Russian democracy, which is just at this time

This speech was published in the May-June 1917 double issue of the popular science journal Priroda, which reprinted it last month in the special celebration issue, No. 750. It is here translated by Vera Rich. rising again to new life with the exact sciences. K. A. Timiryazev, an outstanding scientist and most upright man throughout his long life stubbornly affirmed 'the future belongs to science and democracy'. This is a great truth. And I am profoundly convinced that unless it goes hand in hand with science, democracy will have no future.

For we Russians, it is especially important to equip ourselves with the exact sciences. For Russians more than for any other nation, it is necessary to inculcate respect for intellect, to develop a love for it, and to become aware of its universal force. It is necessary to understand that intellect is our luminary, that it is magma which can warm us from within, that only on its bright wings can we ascend to a height worthy of man, worthy of his sufferings in the search for truth and his unquenchable thirst for truth.

Russian history has woven for our nation a dense net of conditions which from days of old have inculcated and to this very day continue to inculcate the national masses with a suspicious, even hostile attitude to the creative force of the intellect and the great achievements of science. The ideas of Western European culture were introduced into Russia by the nobility. For the majority of the nation the nobleman was only a landlord, a serfowner-what good could come from him? In the peasant's opinion, the scientist was a gentleman and not a worker loosing the fetters of the spirit.

Add to this the church-orientated education of the people, which was irreconcilable to beauty and the force of free and fearlessly investigating thought. And further, add to this the monarchial power which both directly and indirectly suppressed any striving for knowledge. In this sum of influences depressing the vitality of Russian man, one may count many more, but this is not the place to discuss this matter. All these hostile influences should have implanted in the Russian a purely organic, instinctively negative attitude to the great quests of science and to the heretical dogmas of scientists.

What way is there out of this joyless picture? There can be only one way out: science, the most active force in the world, must destroy the ancient mistrust rooted in the Russian people.

\section{Sorry, for copyright reasons some images on this page may not be available online} \section{总}

It must tear out from the people's soul the scepticism of ignorance, it must set free that soul, precious to all of us, from the fetters of prejudice, and giving it the wings of knowledge, must raise up the Russian people to the highest stage of culture.

The people must learn that now they are living in an atmosphere created for them precisely by science. They must understand that the gentleman gathering flowers in the field is not an idler, but a man who is training an agronomist for the village, that the cotton shirts on their back were made in a mill which could not have been built without a knowledge of mathematics, and that the doctor's medicine is the result of the painstaking work of a scientist. They must know that there exists in the world an intellect which tirelessly and lovingly takes thought for their lives...

The atmosphere of science surrounding the city-dweller is even thicker. Here at every step a man may see the triumph of intellect and the enslavement of natural enemies to help him, man. The tramcar and the cinematograph, the automobile and the gramophone, the coat button and the thermometer-all these, useful and ornamental, great and small, were created by science. The process of diffusion of great scientific ideas into the depths of daily life, into dingy Russian existence, is completely incomprehensible to the man in the street, although all his life is penetrated and filled with the ideas of experimental science, crystallised in different forms of practical life.

I understand that telling the man in the street about science's services to him is the task of the populariser and not that of the scientist who is absorbed in his attempt to discover the innermost mystery of existence. But the significance of the popularisation of the exact sciences is enormous and a matter of great responsibility; 
enormous because it is the only thing which can restore health to the psyche of Russian man, and because it alone is capable of creating an atmosphere of sympathy towards the highest aims of science and to evoke the trust of the masses in the force of the intellect.

And hence it seems to me that the foremost problem for us, as far as cultural significance is concerned, is to create in Russia an organisation which would concentrate in itself the whole work of the intellect aimed at the experimental investigation of the great mysteries of existence. I envisage this organisation in the form of a free association of scientists, an association which, working on a world scale, would be in direct spiritual intercourse with similar associations such as, for example, the British, and would strive, in addition to its direct problems, to create in the world a single, planetary receptacle for science which would be the brain and nervous system of our planet.

It is especially necessary to create such an organisation here in Russia, where intellect still does not enjoy its due respect and where its freedom of action was so cynically restricted by the untalented uncultured yoke of the monarchy.

There is no country where science, the highest expression of the life of the nation, could have existed further in the background, where its free striving was thought more dangerous, and where men of science were treated more abominably, than in Russia under the old regime. We ourselves know how brazenly and rudely the hand of politics touched the pure wings of science. You remember how many strong men from among our scientists were forced to leave their homeland, and how many fine talents perished in it, unable to use their forces. But now before men of science a happy possibility has opened up of freshly organising themselves for their wonderful work, for the limitless widening and deeping of the frontiers of the exact science, for the resurrection of the Russian people from the dead.

Permit me to indulge in fantasy-I do this in the profound belief that there is no fantasy which the human will and intellect cannot transform into reality.

I envisage an establishment which I would call the "science city"-a row of temples where each scientist is a priest independently serving his own god. It is a row of excellently equipped laboratories, clinics, libraries and museums, where from day to day the bright intrepid eyes of the scientist gaze into the darkness of the dread mysteries that surround our planet. Here are the forges and workshops where the men of the exact sciences, smiths and jewellers, forge and facet the whole experience of the world, transform it into working hypotheses, into weapons for further quests into truth.

In this "science city" the scientist will be surrounded by an atmosphere of freedom and independence, an atmosphere stimulating creativity, and his work will create in the country an atmosphere of love of intellect, and will evoke among people a proud affection for its power and beauty...

I believe that for men of intellect democracy will take on the significance of an exact science. I know that democracy loves exact science. And I will say that within your will lies the spiritual rebirth of Russia.

Let there be light on Russia.

In these days, when over our sorrowing suffering country there has blazed up a flame, the dawn of a new life, when the Russian people has come to feel the joy of freedom, in these happy and long to be remembered days, men of intellect, men of science, cannot stand aside from great events.

History will call them to the place which by right belongs to them -in the front ranks of creating a new life. It is they who must lead the country. It is their right to feed the spiritually hungry people from the treasure house of planetary intellect, of world science. ...

We have destroyed the old structure of life onty physically-spiritually it is still around us and even within us. Herculean forces will be needed to cleanse oursleves and the whole country from the grime and rust of the monarchical regime...

We need to learn how to live, to work, to love our labour. We need to

\section{Sorry, for copyright reasons some images on this page may not be available online}

Akademgorodok, the science city in Novosibirsk, realised one of Gorky's dreams understand that labour is not an imposition on our will, labour is the free expression of the will to live, and in free labour, just as in love, is concealed the most supreme delight. This must be understood, and only exact science can help us to understand, only by filling ourselves with the spirit of the positive science, can we gradually become healed of our grievous defects.

Citizens!

Culture has three foundations: science, and industry. Permit me to remind you of the great work of the Convention Nationale in France from 17911793. In these three years, the convention, living in an atmosphere of chaos and terror, under the threat of foreign invasion, extended the three departments founded by Buffon to twelve and established a botanic garden which all Europe might envy, founded a Conservatoire of Art and Trade, and three medical schools. The Convention decided, during a war, to strain every nerve to exempt professors and students from military service.

In inexpressibly difficult conditions, the Convention found it possible to publish for farmers "Counsels for autumn sowing" and at its initiative the scientist Dubanton wrote his classic "Handbook for shepherds". The Convention undertook the draining of the marshes, and the organisation of model farms; in 1793, at the height of the terror, it installed a bust of Descartes, the father of French philosophy, in the Pantheon, published the works of Bacon, sent out scientific expeditions, founded an agronomical bureau; moreover, Tampioni, with the backing of the Convention, struck the first blow for the excavation of Pompeii

I would recall that the British Association of Scientists (sic) arose in 1810, at a time when England was on the verge of disaster. It is for us, citizens, to organise in our country its best brains, its creative nerve force; we have to create for the development of Russian science those conditions which would give it the possibility of free and infinite development; we have to concern ourselves, in a friendly way, that our scientists may give the country their maximum creativity.

The higher ascends freely investigating science, the wider its horizons, the more abundant the possibilites of the practical application of scientific knowledge to the conditions of life. In nature, as we know, there is nothing more marvellouus than the human brain, there is nothing more wonderful than the process of thought, nothing more precious than the results of scientific research.

Long live science! 